Article

\title{
Spatial Distribution of Surface Temperature and Land Cover: A Study Concerning Sardinia, Italy
}

\author{
Sabrina Lai ${ }^{\oplus}$, Federica Leone * and Corrado Zoppi ${ }^{\circledR}$ \\ Department of Civil and Environmental Engineering and Architecture, University of Cagliari, Via Marengo 2, \\ 09123 Cagliari, Italy; sabrinalai@unica.it (S.L.); zoppi@unica.it (C.Z.) \\ * Correspondence: federicaleone@unica.it; Tel.: +39-070-6755213
}

Received: 25 March 2020; Accepted: 13 April 2020; Published: 15 April 2020

\begin{abstract}
Land surface temperature (LST) is a key climate variable that has been studied mainly at the urban scale and in the context of urban heat islands. By analyzing the connection between LST and land cover, this study shows the potential of LST to analyze the relation between urbanization and heating phenomena at the regional level. Land cover data, drawn from Copernicus, and LST, retrieved from Landsat 8 satellite images, are analyzed through a methodology that couples GIS and regression analysis. By looking at the Italian island of Sardinia as a case study, this research shows that urbanization and the spatial dynamics of heating phenomena are closely connected, and that intensively farmed areas behave quite similarly to urban areas, whereas forests are the most effective land covers in mitigating LST, followed by areas covered with Mediterranean shrubs. This leads to key policy recommendations that decision-makers could implement to mitigate LST at the regional scale and that can, in principle, be exported to regions with similar climate and land covers. The significance of this study can be summed up in its novel approach to analyzing the relationship between LST and land covers that uses freely available spatial data and, therefore, can easily be replicated in other regional contexts to derive appropriate policy recommendations.
\end{abstract}

Keywords: land surface temperature (LST); land cover; afforestation; green urban grids; regression models

\section{Introduction}

Fast changes aimed at promoting social and economic development have characterized international land cover dynamics in the last few decades [1,2]. Land cover features are related not only to rapid urbanization, but also to processes of higher anthropization, such as the transformation of forest areas into agricultural areas or transitions from woodlands and shrubs to new predominantly homogeneous agrarian areas [3,4]. According to the report of the National Institute for Environmental Protection [5], the artificial land cover in Italy increased by $0.21 \%$ in 2018 , which equals $23,033 \mathrm{~km}^{2}$. Moreover, the increase of artificial land cover is not connected to population increase. Indeed, from 2017 to 2018, the relationship between the land-take increase rate and population change rate takes a negative value, that is -1.20 [5]. In the 2017-2018 period, the main land-cover changes concern transitions from natural and semi-natural areas to urbanized zones, which increase by 700 hectares [5]. The increase in urbanized areas leads to various problems, such as landscape fragmentation, urban heat islands (UHI), and the reduction or loss of ecosystem services. In 2018, 39\% of the Italian territory was found to be characterized by high or very high landscape fragmentation [5]. In relation to UHI in the Italian metropolitan cities, in 2018 the temperature difference between compact urbanized areas and rural zones was higher than $2{ }^{\circ} \mathrm{C}[5]$. In relation to the reduction of ecosystem services, during the 2012-2018 period, the potential loss of crop production due to increased urbanized areas was estimated at around three million quintals of agricultural products that could have been supplied by the lost rural areas [5]. 
Land cover changes, and, in particular, transitions from natural and semi-natural areas to artificial land covers, affect regional and local temperatures [6]. In fact, although urban areas and their surroundings receive the same amount of solar radiation, the local temperatures differ because different surface materials have different heat capacity [7]. From this perspective, land surface temperature (LST) is a significant parameter for investigating the effects of land covers on local temperatures.

Hofierka et al. [8] define LST as "the radiative skin temperature of the ground", affected by solar reflectance, thermal emissivity, and heat capacity. In other words, LST combines interactions between land surface and atmosphere with ground-atmosphere energy fluxes. LST, measured through satellite thermal infrared sensors [9], represents a key climate variable, and its study allows researchers to analyze the behavior of the Earth's environmental system [10].

Therefore, understanding how land cover changes affect climate represents a key element in international debates [11] that highlight that land cover can significantly affect quality of life, that is human health and safety, through its influence on LST [12,13]. The impacts on climate conditions generated by land-cover change processes can be effectively analyzed by assessing the relations between the spatial distribution of LST and that of land covers. The influence of land use/land cover changes on LST variation has been studied by various authors [6,14-18]. Feizizadeh et al. [6] analyze the relations between LST and land use/land cover in Maraqeh County (Iran), using a method based on the application of the Surface Energy Balance Algorithm for Land (SEBAL) to Landsat Enhanced Thematic Mapper (ETM+) imagery. Chaudhuri and Mishra [14] compare land use/land cover and LST differences between India and Bangladesh by analyzing satellite images corresponding to different time periods and by using intensity analysis. Tran et al. [15] focus on the relations between land use/land cover and LST within the urban area of Hanoi by elaborating a three-step methodological approach. In the first step, in relation to each land use/land cover type, normalized vegetation and built-up indices are used to analyze the correlations between LST and vegetation, and man-made features and cropland. The second step implements hot spot analysis and urban landscape analysis to assess how land use/land cover changes affect UHI. In the third step, the authors apply non-metric regression to evaluate future urban climate trends in relation to potential land use/land cover changes. Jiang, Fu, and Weng [16] analyze how some biophysical parameters, such as LST, fractional vegetation cover, normalized difference water index, impervious fractions evaporative fraction, and soil moisture, change in relation to land use/land cover alteration in the case study of Indianapolis, USA, during the 2001-2006 period. Kayet et al. [17] investigate the effects of land use/land cover changes on the distribution of LST by using Landsat Thematic Mapper and ETM+ data concerning 1994, 2004 and 2014. Sahana, Ahmed, and Sajjad [18] investigate the relationships between land use/land cover change and LST by implementing the split-window algorithm and spectral radiance model in relation to the Sundarbans Biosphere Reserve in India.

Various studies concerning the influence of land use/land cover changes on LST variation have been carried out in relation to Italian case studies [19-22]. Zullo et al. [19] study the relationship between LST variations and the increase in urbanized areas from 2001 to 2011 in the Po Valley through different urban growth spatial patterns. Guha et al. [20] investigate the relationship between the estimated LST and two indexes, that is the normalized difference vegetation index (NDVI) and the normalized difference built-up index (NDBI) in the cities of Florence and Naples by using Landsat 8 data. Stroppiana, Antoninetti, and Brivio [21] focus on the relationship between spatio-temporal LST variation and land cover, topography, and potential solar radiation in four southern Italian regions, Basilicata, Campania, Molise, and Apulia. Scarano and Sobrino [22] focus on the relationship between LST variation and landscape composition and urban morphology in the city of Bari.Many of these researchers focus on urban areas, while the regional dimension is somewhat neglected in studies that analyze the correlation between land use/land cover changes and LST. Therefore, although various authors have studied the relations between land use/land cover and LST, further analysis may provide more accurate parameters in order to understand this complex relationship [23] at a wider scale. Moreover, a mere understanding of this relation is not sufficient to deal with the problem of climate 
change, while new policies and strategies should be included within spatial planning at the regional and local levels. The research proposed in this study demonstrates various innovative aspects. The first point concerns the choice to focus on a regional scale that, as mentioned above, has not received enough attention within the literature, where the urban dimension takes a privileged role in studies concerning the relationship between LST variation and land use/land cover. Secondly, this study takes a step forward compared to previous studies in that it not only attempts to identify the relationships between LST patterns and land use/land cover, but also provides strategies, policies implications, and recommendations concerning the governance of land cover changes aimed at mitigating LST increase at a regional level. The third and final innovative point concerns the choice of the Sardinia region as a case study, since the influence of LST variation on land use/land cover change has not been investigated in this specific context.

In this study, the connections between anthropization and natural conditions and the spatial taxonomy of LST are analyzed in order to assess whether, and to what extent, land covers and their transitions affect the spatial layout of heating phenomena at the regional level. The distribution of land cover characteristics is based on the spatial units retrieved from Copernicus [24]. These spatial units, classified according to the CORINE (Coordination of Information on the Environment) Land Cover (CLC) framework of the European Environment Agency (EEA) [25] and aggregated according to the LEAC (Land and Ecosystem Accounting) classification [26], are taken as the spatial basis to explain LST distribution.

The methodological approach applied in this study, which is based on a cross-sectional spatial inferential analysis, provides results that can be used in two ways. On the one hand, the differential impacts of different land cover types on LST are characterized with reference to the LEAC classification, and the most critical land covers related to heating phenomena are identified. On the other hand, a number of planning policies concerning land cover changes are defined, with the ultimate aim of decreasing LST.

The Sardinian region is taken as the spatial context to implement the correlation analyses described above because its climate homogeneity and self-containment allow for a pretty straightforward identification of the regional boundaries. The correlation between the spatial distribution of LST and land cover reveals that urbanization and the spatial dynamics of heating phenomena are closely connected. The discussion implied by the outcomes can be easily exported to assess the analyzed relationships with reference to other regional contexts. The comparison of analogies and differences are quite effective and useful in identifying stylized facts and policy implications. Therefore, this study answers the following research questions:

1. What are the land covers that mainly influence the LST spatial distribution in the Sardinian case study?

2. What policies and strategies might be helpful in mitigating LST at the regional scale?

The study is structured into six sections. The first section identifies the wider context and the debates to which the study is contributing. The second section describes the study area, data, and methodology used in this study. The third section presents the results that are discussed in the fourth section, where the main findings are interpreted and compared with findings from similar studies. The fifth section provides recommendations in terms of strategies and policies, and finally, the sixth section proposes concluding remarks and future directions of the research.

\section{Materials and Methods}

\subsection{Study Area}

With a size of $24,000 \mathrm{~km}^{2}$ and approximately $1850 \mathrm{~km}$ of coastline, Sardinia is one of the major Mediterranean islands (Figure 1). The island, which from an administrative point of view is an Italian autonomous region populated by around 1.6 million inhabitants (as of December 31, 2018: [27]), is taken 
as the spatial context for this study because its climate homogeneity and self-containment allow for a pretty straightforward identification of the regional boundaries.

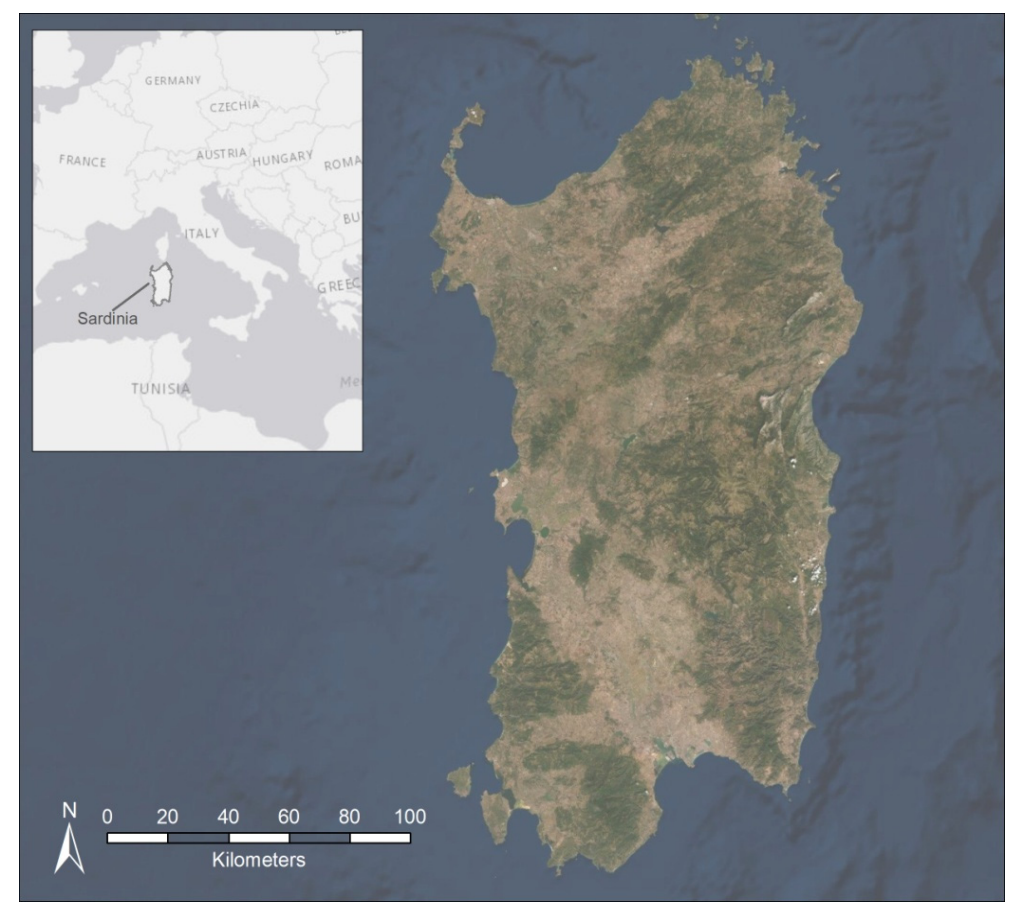

Figure 1. Case study: Sardinia within the Mediterranean Sea basin. Basemaps: Esri "Imagery" and Esri “Light Canvas”.

Its climate is typically Mediterranean: winters are mild and moderately rainy, while summers are quite hot and dry [28]. The landscape is rugged, with only a couple of major plains, mostly dedicated to agriculture, and a series of minor coastal valleys where coastal urbanization is increasingly taking over agricultural and farming uses. Hills characterize Sardinian landscapes, and some scattered groups of mountains, such as Limbara, Sette Fratelli, and Gennargentu (comprising Punta La Marmora, the highest Sardinian peak at $1834 \mathrm{~m}$ ), stand out [29].

A large part of the island is covered by scrubs or herbaceous vegetation associations [30]. Agriculture and pasture are also significant, especially in the plains and hills [28], while artificial land, according to the latest report issued by the National Institute for Environmental Protection [5] (p. 48), amounts to $3.76 \%$ of the region; this is approximately half of the national average $(7.64 \%)$.

\subsection{Data}

Landsat 8 OLI (Operational Land Imager) and TIRS (Thermal Infrared Sensor) images are freely available from the US Geological Survey website [31], where data can be searched and retrieved based on spatial and temporal criteria. For spatial criteria, a bounding box having minimum latitude 38.8, maximum latitude 41.4, minimum longitude 8 , maximum longitude 10 was selected; for temporal criteria, the spring interval spanning from 15 April 2019 to 31 May 2019 was chosen. Springtime in Mediterranean areas, with vegetation in full swing, allows for better capturing of the differences between artificial and vegetated areas as regards surface temperature; however, early spring images are likely to be undesirable because of high cloud cover. For this reason, early spring days (i.e., the end of March and the beginning of April) were taken out. June is problematic, because the Mediterranean climate implies high temperatures and the early start of summer, with annual crops such as wheat or forage being yielded and pastures starting to dry up. This means that soils are left bare or partly bare, and this in turn makes it impossible to fully appreciate how vegetation affects LST. The five selected multi-band images are listed in Table 1, and their footprint is shown in Figure 2, which shows 
the spatial layout of the two overlapping scenes taken on 16 May and 23 May 2019 (192 and 193, respectively, represented as yellow-dashed rectangles) to which the Landsat images (i.e., the colorful squares within the yellow-dashed rectangles) belong. The cell size of the thermal bands (10 and 11), for each image, was 30 meters.

Table 1. Landsat 8 Operational Land Imager-Thermal Infrared Sensor (OLI-TIRS) images selected for this study.

\begin{tabular}{ccc}
\hline Image Code & Date & Scene \\
\hline LC08_L1TP_193031_20190523_20190604_01_T2 & 23 May 2019 & 193 \\
LC08_L1TP_193032_20190523_20190604_01_T1 & 23 May 2019 & 193 \\
LC08_L1TP_193033_20190523_20190604_01_T1 & 23 May 2019 & 193 \\
LC08_L1TP_192032_20190516_20190521_01_T2 & 16 May 2019 & 192 \\
LC08_L1TP_192033_20190516_20190521_01_T1 & 16 May 2019 & 192 \\
\hline
\end{tabular}

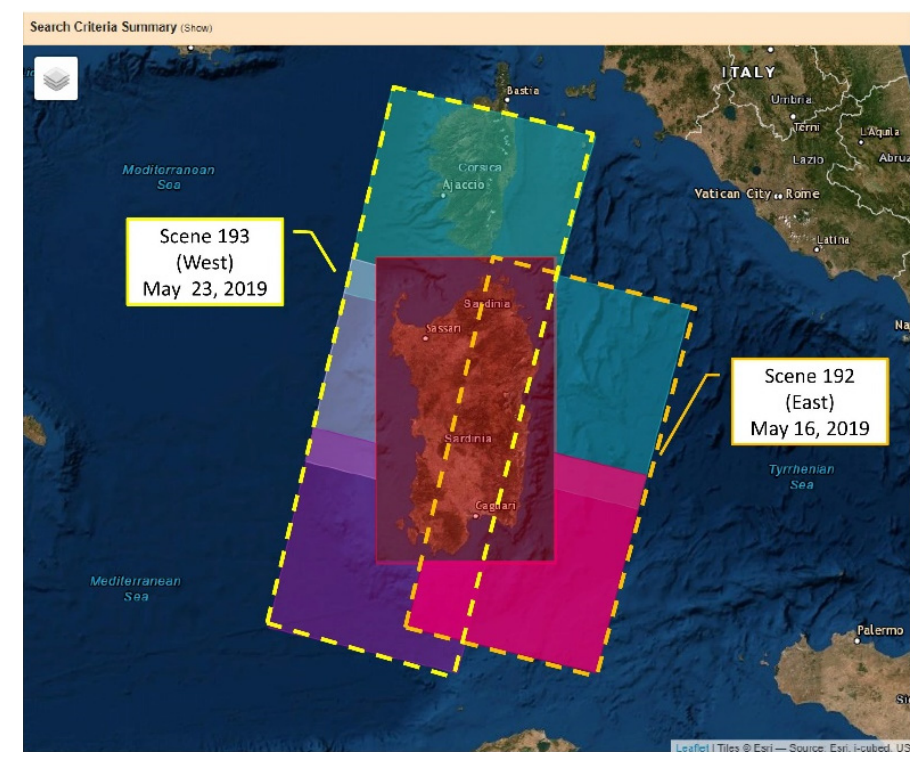

Figure 2. Footprints of the selected Landsat 8 OLI-TIRS images (https://earthexplorer.usgs.gov/).

2018 land cover data, classed following the CORINE third-level nomenclature [32], were retrieved from the Land Monitoring Service [33] of the European Union's Copernicus Earth Observation Program. CLC is an EU program that has been providing consistent information about land covers across Europe over time since 1990. Datasets, which are derived from the photointerpretation of satellite images, are provided in both raster and vector formats, and their minimum mapping unit (MMU) is 25 hectares.

Finally, a Digital Terrain Model (DTM) is available for Sardinia from the regional geoportal [34]. It was produced by the regional office for cartography and spatial datasets in 2011, and its cell size equals 10 meters.

\subsection{Methodology}

The methodological approach of this study develops as follows. First, LST was extracted and mapped following the procedure described in the Section 2.3.1. Secondly, land covers and elevation data were processed (Section 2.3.2) with the aim of building a spatial dataset that brought together the three layers (Section 2.3.3) and fed a multiple regression analysis, implemented to estimate the relationships between different land covers and LST (Section 2.3.4). A graphical summary of the methodology adopted in this study is provided in Figure 3. 


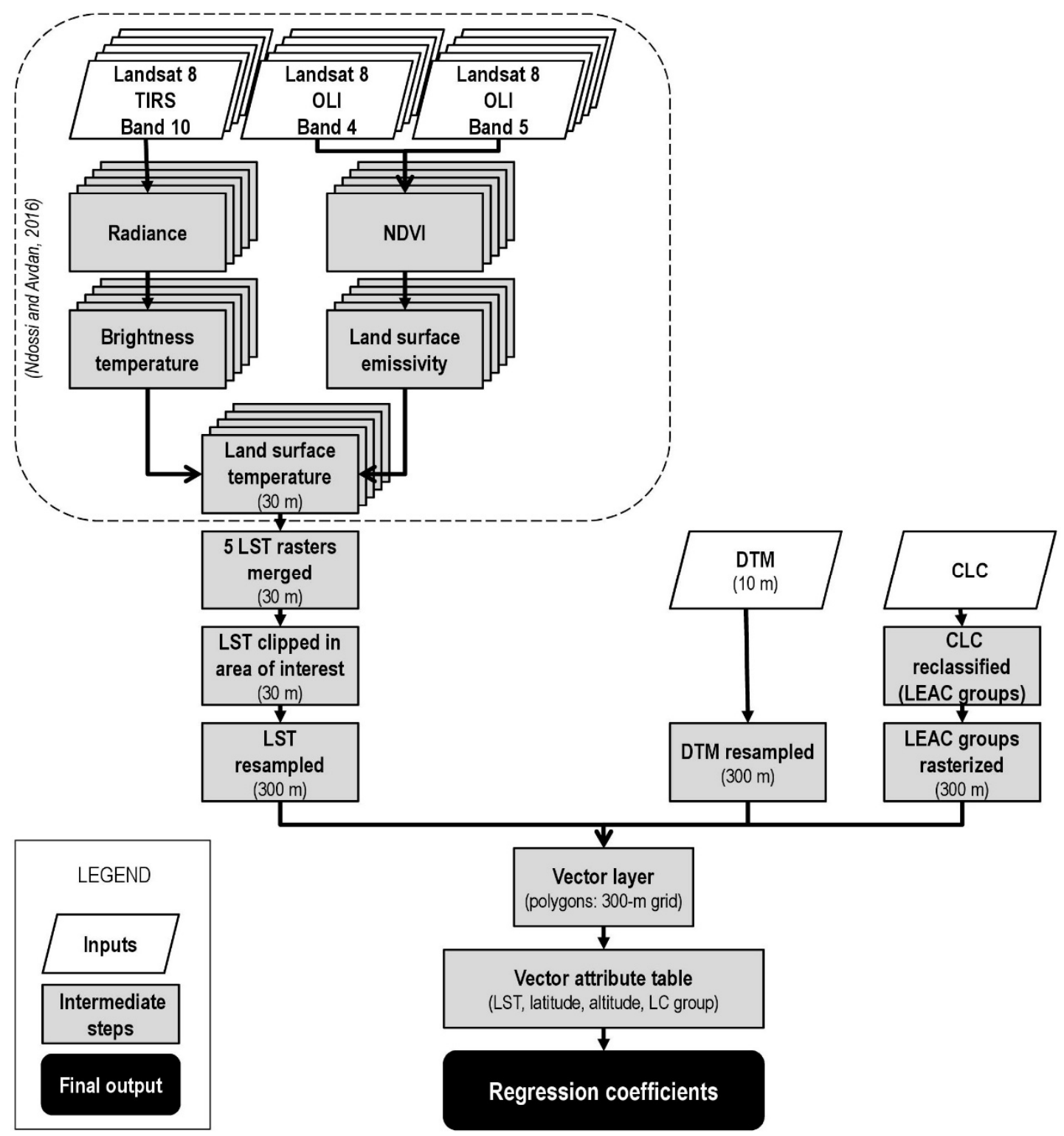

Figure 3. Graphical summary of the methodology. (NDVI: Normalized Difference Vegetation Index; TIRS: Thermal Infrared Sensor; OLI: Operational Land Imager; LST: Land Surface Temperature; LEAC: Land and Ecosystem Accounting; CLC: Corine Land Cover).

\subsubsection{LST Extraction and Mapping at the Regional Scale}

A QGIS plugin implemented by Ndossi and Avdan [35] was used in this study. The plugin has been employed to extract LST from Landsat images in various studies, mainly at the city level, to assess the significance of urban trees in mitigating temperatures [36], to investigate UHI phenomena [37], or to estimate the impact of urban land-use change on LST [38]. For each image listed in Table 1, a five-step process was therefore performed through the plugin; the process is fully explained in Appendix A and can be summarized as follows.

In the first step, the top-of-atmosphere spectral radiance was calculated for each pixel [39]; subsequently, the top-of-atmosphere spectral radiance was converted into the top-of-atmosphere brightness temperature [39]. Next, the NDVI was calculated using Landsat 8's bands 4 and 5 images as inputs [40]; NDVI makes it possible to calculate, in the fourth step, Land Surface Emissivity (LSE) through various algorithms. Among those implemented in the plugin, Zhang, Wang, and Li's algorithm [41], which builds upon van de Griend and Owe's findings concerning the correlation 
between LSE and NDVI [42], was chosen here because it was reported to yield the best results [35] for LST retrieval. Finally, in the fifth step, LST was calculated using the so-called "Planck function" [43], which has been reported to be "easier to use in comparison to the other algorithms as it does not require atmospheric variables" [35] (p. 28).

Through these steps, five LST raster maps (one for each Landsat image listed in Table 1 and each having resolution 30 meters) were obtained. The five LST images were then merged, so as to obtain a single LST image for the whole region (in the case of overlapping pixels, the maximum LST value, consistently corresponding to pixels belonging to scene 193 produced on 23 May was retained), which was next resampled to a $300-\mathrm{m}$ cell size so as to lower the resolution, hence reducing computational efforts in the subsequent steps.

\subsubsection{Land Covers and Elevation}

From the European 2018 CLC vector dataset, polygons concerning Sardinia were first extracted and next reclassified based on the LEAC classification defined by the EEA [26] (p. 98) and used for land cover accounts. Table 2 shows the LEAC-related macroclasses as groups of the 44 third-level classes of the CLC dataset. The reclassification provided a LEAC-based spatial taxonomy which was afterwards used to assess the relationships between LST and land covers.

Table 2. CORINE land cover classes and groups.

\begin{tabular}{|c|c|c|c|c|c|}
\hline \multirow[b]{2}{*}{ URB } & \multirow[b]{2}{*}{ Artificial (urbanized) areas } & \multicolumn{4}{|c|}{ CORINE Land Cover Classes ${ }^{1}$} \\
\hline & & 1.* & & & \\
\hline $\mathrm{APC}$ & Arable and permanent crops & 2.1.* & 2.2.* & 2.4.1 & \\
\hline MCP & Mosaic crops and pastures & 2.3.* & 2.4 .2 & 2.4 .3 & 2.4 .4 \\
\hline FSW & Forests, shrubs, and woodlands & 3.1.* & 3.2 .4 & & \\
\hline HNGS & Heathland, natural grasslands, and sclerophyllous vegetation & 3.2.1 & 3.2 .2 & 3.2 .3 & \\
\hline OPSP & Open spaces with sparse or absent vegetation & 3.3.* & & & \\
\hline WAT & Water bodies and wetlands & $4 .^{*}$ & 5.* & cept 52 & sea) \\
\hline
\end{tabular}

The asterisk $\left(^{*}\right)$ marks any sub-classes of a given class, or any sub-sub-classes of a given sub-class. (CORINE: Coordination of Information on the Environment).

Next, the resulting layer was converted into a raster map with a cell size of 300 meters (where the grid was the same as that of the resampled LST). Each cell was assigned a value corresponding to the prevailing land cover group.

As for elevation, the regional DTM was resampled so as to obtain a new raster file with the same cell size (300 meters) and grid as the LST and LC group raster images. As for the resampling technique, linear interpolation, appropriate for continuous data [44] as elevation, was used to derive the cell's altitude.

\subsubsection{Input Table for the Regression}

A vector layer (shapefile) was created. Polygons in this shapefile spatially coincide with pixels belonging to the three raster maps derived as per the previous subsubsections; hence, every polygon is a $300 \mathrm{~m}$ by $300 \mathrm{~m}$ square in the projected reference system EPSG 32632 [45].

Each polygon was then assigned the following attributes: the LST value of the corresponding cell, its prevailing land cover group, and its altitude. Furthermore, the latitude of the polygon's centroid (in the reference system EPSG 32632) was added, since the temperature is expected to be dependent on the latitude.

Finally, a field taking the value 1 (pixels pertaining to scene 193, i.e., the western one; see Figure 2) or 0 (pixels only pertaining to scene 192, i.e., the eastern one; see Figure 2) was added. The pixels featuring in both scenes were regarded as belonging to scene 193, which was consistent with the fact that the maximum LST value, steadily corresponding to scene 193, was retained when merging the five LST images. 


\subsubsection{Land Covers and LST}

The polygons described in the previous subsubsection were identified as the spatial units for estimating a multiple linear regression which takes the following form:

$$
\mathrm{LST}=\beta_{0}+\beta_{1} \mathrm{URB}+\beta_{2} \mathrm{APC}+\beta_{3} \mathrm{MCP}+\beta_{4} \mathrm{FSW}+\beta_{5} \mathrm{HNGS}+\beta_{6} \mathrm{OPSP}+\beta_{7} \mathrm{ALTIT}+\beta_{8} \mathrm{LATD}+\beta_{9} \mathrm{~W}
$$

where:

- explanatory variables from URB through to OPSP, which represent the LEAC groups, are dichotomous variables; each variable can take either of the two values, 1 or 0 , according to whether the area size of a LEAC group in a cell takes the largest value with respect to the area sizes of the other groups; therefore, if in a cell the URB group shows the largest area size, the variable URB equals 1 , otherwise it equals 0 ; if in a cell the APC group shows the largest area size, the variable APC equals 1 , otherwise it equals 0 , and so on; each coefficient estimated by regression (1), $\beta_{i}, i=1, \ldots, 6$, identifies the change in LST related to a cell in case it shows the largest area size identified by the variable associated to the coefficient $\beta_{i}$ (i.e., URB, APC, etc.) with respect to the basic condition that the largest area size of the cell is identified by the variable WAT (Wetlands and water bodies); the coefficients estimated by regression (1), $\beta_{\mathrm{i}}, \mathrm{i}=1, \ldots, 6$, define a taxonomy of the zone types based on the quantitative contribution to LST expressed by the values of $\beta_{\mathrm{i}}, \mathrm{i}=1, \ldots, 6$;

- $\quad$ ALTIT is the altitude in meters related to the polygon, calculated as described in Section 2.3.2.;

- $\quad$ LATD is the latitude in meters of the polygon's centroid, as per Section 2.3.3.;

- W (standing for "West") is a dichotomous variable which can take either of the two values, 1 or 0 , as described in Section 2.3.3.

The results from the multiple linear regression were used to identify the quantitative effects of different land covers on LST and their ordinal ranking; for each LEAC group, the rank depended on the value of the coefficients $\beta_{\mathrm{i}}, \mathrm{i}=1, \ldots, 6$, of regression (1).

As in many articles regarding spatial phenomena featured by multiple variables, a multiple linear regression was used since no priors were available as regards the relations between the covariates representing the determinants of the phenomenon at stake (see, for example, [46-49]).

That being so, the surface, whose equation was unknown, representing an n-dimensional phenomenon, e.g., a spatial phenomenon, as a functional relation between $\mathrm{n}$ variables, was approximated, point by point, by the point neighborhood identified by the tangential hyperplane. The neighborhood shared by the surface, whose equation was unknown, and by the tangential hyperplane, whose equation was known, was identified by the linear relation between the covariates, as a locally identified approximation of the unknown general relation between the factors. A multiple linear regression such as (1) provided the estimates of the coefficients of the linear equation, which demonstrated the trace of a tangential hyperplane over a nine-dimensional unknown surface which represented the functional relation between LST and its covariates [50,51].

The variables ALTIT and LATD were used to control the impacts of the altitude and latitude of a cell on the LST; as a consequence, if the estimates of the coefficient $\beta_{7}$ and $\beta_{8}$ were significant with reference to their $p$-values, this would entail that the altitude and latitude generate effects on the LST, whose expected signs are negative, since it is expected that the higher the altitude and the greater the latitude, the lower the LST, everything else being equal. Finally, the variable W was used to control the impact of the date of the satellite images, which should show a systematic difference between 23 May 2019 and 16 May 2019, since 23 May was a clear sunny day whereas 16 May was partly cloudy. That being so, the cells whose LSTs were extracted on 23 May, belonging to scene 193 and hence located on the western side of the island, should show higher LSTs than the others, everything being equal, and the expected sign of $\mathrm{W}$ should be positive. 
A standard significance test based on $p$-values was implemented as regards the coefficients of the regressions, to detect whether they are significantly different from zero. If $p$-values were lower than $5 \%$, then the explanatory variables' effects on LST could confidently be considered important.

\section{Results}

The outcomes of the methodological approach discussed in the second section are presented as follows. In the first subsection, the spatial layout of the LST taxonomy is described; in the next subsection, the estimates of regression model (1) are reported and the effects of different LEAC macroclasses on LST are presented, which define an ordered scale whose lowest level is represented by water bodies and wetlands and upper level by urbanized land.

\subsection{LST Spatial Taxonomy Results}

Some outputs of the LST extraction process described in Section 2.3.1. are shown in Figure 4, which clearly shows that some parts of the island were covered by clouds when the Landsat images where produced-this locally affected both NDVI and LST values. Hence, such pixels (25,099 out of 266,818 ) were subsequently removed, and Figure 5 shows the spatial distribution of LST minus the cloudy cells, of LEAC groups (obtained as per Section 2.3.2), and of elevation (obtained as per Section 2.3.2) that were used to develop the matrix that fed the regression described in Section 2.3.3.

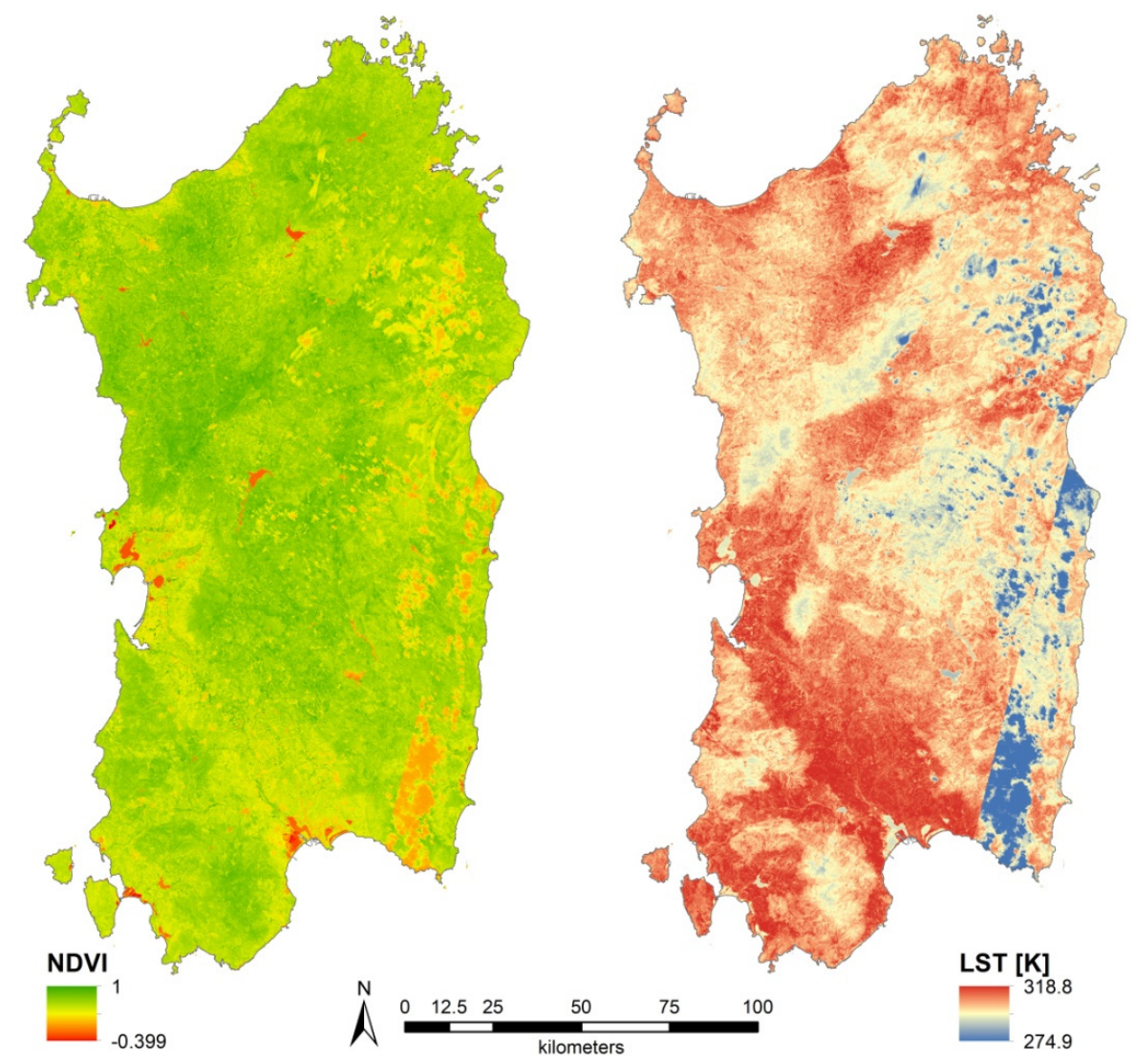

Figure 4. Spatial layout of NDVI and LST in Sardinia, May 2019. 

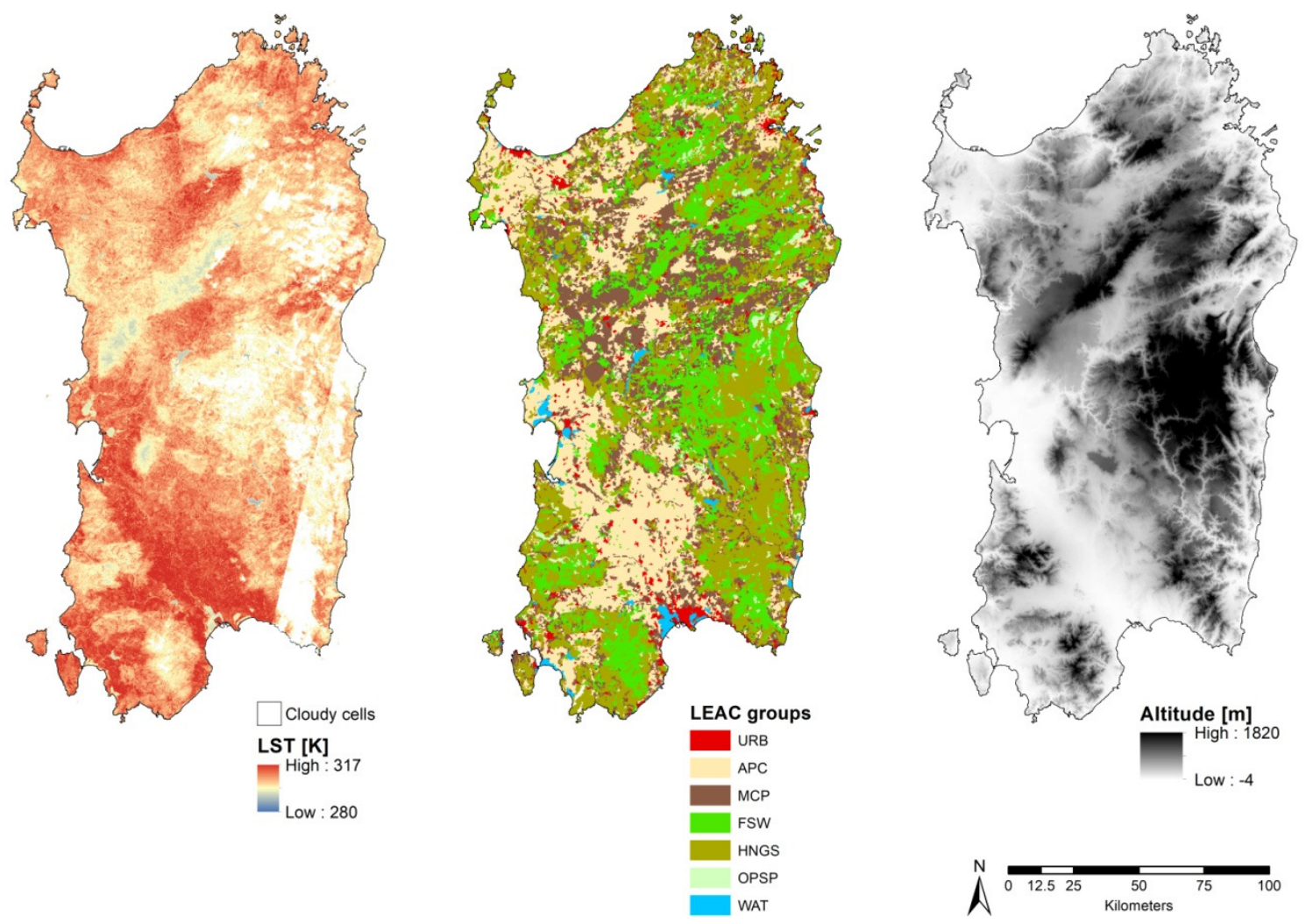

Figure 5. Spatial layout of LST with cloudy cells removed, of LEAC groups, and of elevation. (LEAC: Land and Ecosystem Accounting).

\subsection{Regression Results}

The estimates of the regression identify the impacts of the land cover macroclasses of the LEAC on the LST. The estimates of the coefficients of the Boolean covariates define the differential effects of each variable on LST change with respect to "Water bodies and wetlands", whose effect on LST is the lowest among the LEAC macroclasses.

Table 3 shows the results of the regression model.

Table 3. Regression results.

\begin{tabular}{cccccc}
\hline Explanatory Variable & Coefficient & Standard Deviation & t-Statistic & $p$-Value & $\begin{array}{c}\text { Mean of the } \\
\text { Explanatory Variable }\end{array}$ \\
\hline URB & 8.918 & 0.0531 & 167.991 & 0.000 & 0.032 \\
APC & 8.515 & 0.0460 & 185.274 & 0.000 & 0.269 \\
MCP & 7.413 & 0.0465 & 159.529 & 0.000 & 0.228 \\
FSW & 4.786 & 0.0476 & 100.556 & 0.000 & 0.150 \\
HNGS & 6.272 & 0.0463 & 135.428 & 0.000 & 0.293 \\
OPSP & 7.349 & 0.0602 & 122.113 & 0.000 & 0.017 \\
ALTIT & -0.00638 & -0.0000218 & -292.404 & 0.000 & 317.248 \\
LATD & -0.0000157 & -0.0000000781 & -200.735 & 0.000 & $4,438,355.893$ \\
W & 4.311 & 0.0242 & 178.260 & 0.000 & 0.951 \\
\hline
\end{tabular}

Dependent variable: LST: Mean: 302.230 K; Standard deviation: 3.801; Adjusted R-squared: 0.571.

The estimates of the coefficients of the altitude and latitude variables are significant in terms of $p$-value hypothesis testing, and they show the expected sign. As a consequence, it can be stated that the higher the altitude, or the larger the latitude, the lower the LST. On average, an increase of $100 \mathrm{~m}$ in altitude will imply a decrease of $0.64 \mathrm{~K}$ in temperature, whereas an increase of $10 \mathrm{~km}$ in latitude will entail a decrease of $0.16 \mathrm{~K}$ in temperature. Moreover, the coefficient of the dichotomous variable $\mathrm{W}$ is significant and it shows the expected sign as well, which implies that, on average, a cell whose LST 
was related to the satellite images taken on 23 May is $4.3 \mathrm{~K}$ higher than the LST of a cell whose LST was related to the satellite images taken on 16 May.

Therefore, the estimates of the three control variables' coefficients are significant and show the expected sign, and, that being so, it is pretty straightforward to identify the implications concerning the differential effects on LST derived from the six LEAC macroclasses on the basis of the estimated coefficients of the six dichotomous variables from URB through OPSP.

The estimated coefficients of the six dichotomous variables are significant with respect to the standard test based on $p$-values described at the end of Section 2. The estimates of the coefficients entail the following implications, which all assume the condition "everything else being equal".

First, the highest effect on LST is shown by URB. The estimated coefficient implies that, on average, urbanized (artificialized) cells present an LST higher by: $8.9 \mathrm{~K}$ than WAT cells (water bodies and wetlands); $0.4 \mathrm{~K}$ than APC cells (arable and permanent crops); $1.5 \mathrm{~K}$ than MCP cells (mosaic crops and pastures) and OPSP (open spaces with sparse or absent vegetation); $2.6 \mathrm{~K}$ than HNGS cells (heathland, natural grasslands, and sclerophyllous vegetation); $4.1 \mathrm{~K}$ than FSW (forests, shrubs, and woodlands).

Secondly, intensive farming (APC) generates impacts on LST similar to urbanization, even though it is not characterized by the soil-sealing phenomenon.

Thirdly, extensive farming and pastures (MCP), and bare land or poorly vegetated soils (OPSP) are correlated to lower LST, and their impacts on LST are similar to each other.

Fourthly, the two LEAC non-agricultural vegetated macroclasses are the most effective as regards mitigation of the land surface heating phenomenon. Forests, shrubs, and woodlands (FSW) show the largest positive impact on LST mitigation.

\section{Discussion}

The ordered scale of the effects of the LEAC macroclasses on LST derived from the estimates of the regression model shows a number of aspects consistent with the findings reported in the current literature. The most relevant impact on increases in LST is represented by urbanized land, whose differential effect on LST with respect to water bodies and wetlands is about $9 \mathrm{~K}$. There are several reasons explaining this outcome. Sealed soils either limit or prevent air circulation and the impact of downwind cooling [52]. In heavily urbanized areas, the thermal comfort of vegetated areas is almost completely missing [53,54]. Artificial surfaces make evapotranspiration almost impossible, and, as a result, LST and air temperature are comparatively higher than in non-artificial surfaces [55]. In addition, the surface materials used in urban areas have higher radiant temperatures [23]. The increasingly frequent heat-wave and heat-island phenomena would be mitigated by the canopies of woodland trees and shrubs, which are rare or absent in urbanized areas [56]. Moreover, a recent study proposed by Fonseka et al. [7] highlights two important findings. Firstly, the increase in urban areas often entails a population increase and therefore higher values of LST are affected by higher heat discharge due to human activities. Secondly, in their study area (Colombo Metropolitan Area, Sri Lanka) bare lands show high LST values because in these areas new developments are taking place.

In relation to intensive farming, the outcomes of the regression model show that the impact on LST increase generated by intensive farming areas is only slightly lower than that of urbanized land, that is, about $8.5 \mathrm{~K}$ higher than that of the water bodies and wetlands LEAC macroclass. Indeed, the areas belonging to the APC macroclass reveal conditions that are very similar to those of the URB macroclass. Even though the soil is not sealed, arable land and permanent crops generate negative effects on downwind cooling and air circulation which make LST comparatively higher than those of the other LEAC macroclasses except artificial land. Even the thermal comfort and evapotranspiration provided by areas characterized by intensive agriculture are very low with respect to that of the other LEAC macroclasses, with the exception of the URB macroclass, since in artificial areas trees are almost-totally absent and soils are generally covered by dense low-growing vegetation $[57,58]$. In general, transitions from natural areas to intensive farming modify some important variables in terms of local climate, such as surface roughness of vegetation, leaf conductance, and soil moisture. 
Moreover, arable and permanent crops need constant irrigation that entails, on the one hand, higher physical evaporation and transpiration and, on the other hand, a lower sensible heat flux that cools the land surface. The consequent moisture flux in the atmosphere produces latent heat that influences convection and precipitation by enhancing the moist static energy in the convective boundary layer [59].

HNGS shows lower LST compared to other macroclasses due to the presence of vegetation that reduces the amount of stored heat in the soil through transpiration [60]. In fact, vegetation affects the microclimate through shading that prevents incoming solar radiation reaching the land surface through evapotranspiration and by affecting air movement and heat exchange [53]. However, as pointed out by Zhou et al. [61], the effect of vegetation on LST is largely influenced by seasons. The results of their study show that, although the share of the tree canopy is responsible for $69 \%$ of the total variation of LST during summer, variables concerning tree canopies are not good predictors of LST during spring and winter. During winter, this different behavior is strongly influenced by leaf fall, which reduces the evapotranspiration of canopy trees with a consequent lower LST regulation.

The results of this study reveal that forests, shrubs, and woodlands show the larger positive impact on LST mitigation. According to a study carried out by Walawender et al. [62] in relation to Krakow, forests and waters show low values of LST. However, their behavior changes during the year. In March, before the period of growth between germination and flowering, waters show considerably lower values of LST compared to forests. In May, when the vegetative period is just beginning in Poland, the LST values of forests are slightly lower than the values of waters. In June and August, at the end of the vegetative period, forests and waters take the same values. This different behavior is caused by evapotranspiration that is superior at the peak of the vegetative period when air temperature goes up. The same study shows that the LST of arable land, pastures, and permanent crops is affected by seasons. At the beginning of the vegetative period, the LST of arable land is slightly higher than the mean values. Before the vegetative period, the LST values of permanent crops and grassland are higher than the mean values. This temperature variation can be explained through the state in which arable land is kept after the planting period, that is not covered by any vegetation. In April-May, during the early vegetative season, arable land shows the same thermal properties as bare soil, and its LST values are higher than areas covered with vegetation.

On the other hand, pastures are perennial; therefore, the early vegetative period is characterized by a closed canopy different from the bare soil that characterizes arable land in the same vegetative period. Moreover, the capacity of regenerating living biomass is strongly connected with precipitations that limit a constant forage production during the vegetation period [63].

It must be noted that lowering LST in rural areas has relevant implications in terms of mitigation of water shortages and of the entailed negative economic impacts and social problems [64]. As per Sruthi and Aslam [65], LST and NDVI are strictly negatively correlated in agricultural areas, which implies that the higher the LST the lower the vegetation density. This outcome is particularly important with regards to periods of drought, characterized by productivity decline determined by poor rains and soil humidity [65]. In turn, the decline in productivity can possibly generate significant consequences in terms of economic and social unrest [66,67]. This is an outstanding issue with reference to Sardinia, where agricultural area comprises about one half of the regional land $\left(11,500 \mathrm{~km}^{2}\right)$ and employment in agriculture is about $7.5 \%$ of total employment (41,000 people) [68].

Finally, two main limitations of this study should be taken into account. First, validation would be needed and, indeed, is missing, as regards the LST spatial layout. The theoretical LST data implemented into model (1) should be compared to direct LST observations in order to justify their use to define and develop spatial planning policies aimed at decreasing LST and at mitigating its negative impacts on urban and rural areas. A clear-cut and straightforward validation methodology is described and applied by Nguyen et al. in a recent article concerning Hanoi [1]. Secondly, at present, the Sardinian municipalities and the regional administration seem very far from understanding the potential of policies geared towards decreasing LST, such as urban green and blue grids, green roofs and facades, and afforestation. As a consequence, public commitment and investment are quite low, and the lack of 
planning experiments is likely to make it very difficult to ensure that these kinds of measures would be implemented into planning practice in the short run. Under this perspective, two important reference points are the approaches adopted in the London Green Grid experiment [69] and in the afforestation of farms located in the Northern Uplands of Vietnam [70].

\section{Urban Planning and Policy Implications}

A number of policy recommendations are implied by the outcomes of this study.

First, high LSTs in the consolidated fabric of cities, towns, and small villages, which may possibly develop into heat islands and waves, can be mitigated through the implementation of widespread urban microscale operations, such as the planting of trees, the increase in the endowment of urban green zones through the plantation of new areas and/or the enlargement of existing ones [53]. Other microscale measures consist of the realization of green facades and walls, and green and blue urban grids. There are several examples of these planning policies implemented in different urban contexts. A pioneer and outstanding primer is the London Green Grid [69]. This document is based on a predicted increase of $3{ }^{\circ} \mathrm{C}$ by 2050 in the London metropolitan area, which will generate negative impacts on several determinants of the metropolitan quality of life, such as public health, drinking water production, dryness, vegetated areas, and insects and vermin infestation. The urban planning concepts of the primer were implemented into the plans for the East London Green Grid, which entails a system of green and blue infrastructures that generate a metropolitan landscape characterized by the integration of the built environment, where people live and work, featured by almost-sealed-soil areas, public transport hubs, and the Green Belt, which includes London and the Thames [71].

The microscale planning measures aimed at decreasing LST in urbanized contexts are based on the provision of ecosystem services regulating LST, which entail important benefits in terms of urban and metropolitan quality of life [72]. The implementation of these measures implies the integration of different kinds of planning policies, in order to induce virtuous behaviors on behalf of the local communities, organized groups of residents, building enterprises, and public administrations. A central issue is that the value of urban land is strictly related to its permitted building volume, whether it is residential or devoted to services or infrastructure. That being so, the development of urban land uses consisting in the plantation of new green areas and/or the enlargement of existing ones, which imply that these areas would decrease their value substantially by losing their building potential, should be implemented through the integration of appropriate planning measures. On the one hand, it is necessary to enact a regulatory system whose rules should state that new settlements, and, perhaps, existing ones, have to be endowed with a certain amount of vegetated areas, either by devoting part of the facades and roofs to greenery, or by binding more-or-less large areas to be part of blue or green grids, such as in the case of East London $[73,74]$. On the other hand, a system of financial incentives should be put in place so as to make buildings endowed with green facades and roofs, as well as the realization of green and blue grids in the existing urban neighborhoods and in the new developments, attractive in terms of private investment $[75,76]$. Incentives may include the reduction of impact fees, cuts to value-added tax and to tax on property value, public funding granted to developers to improve the quality of urban landscapes through the realization of adequate green and blue infrastructure, and so on $[77,78]$. Finally, public commitment to the increase in the urban endowment of blue and green grids and infrastructure should be identified clearly through the implementation of public planning policies, for example through compulsory purchase orders concerning municipal areas where urban greening plans, such as the East London Green Grid, are to be implemented [79,80].

Secondly, as regards non-artificial land, the most effective LEAC macroclasses in lowering LST are forests, shrubs, and woodlands (FSW) and heathland, grasslands, and sclerophyllous vegetation (HNGS),whereas the impacts of intensive and extensive agriculture-related land covers (APC and $\mathrm{MCP}$ ), and of open spaces (OPSP) are very close to the negative impact of urbanized land. A pretty straightforward implication is that the LEAC macroclasses characterized by the lowest degree of anthropization, such as FSW and HNGS, should be targeted by public policies in order to implement 
the mitigation of the land surface heating phenomenon. Policy measures should aim at supporting stepwise transitions from APC, MCP, and OPSP to HNGS and FSW.

Afforestation is the main road to identify the implications of the regression model results as regards lowering LST in rural areas [81]. A detailed discussion on land use transition from agriculture to forests, proposed in a study on socio-economic drivers of farm afforestation decision-making [82], argues that a relevant obstacle is represented by the non-monetary benefits of farming [83], which is connected to the flexibility of activities related to agriculture [84] and to the fact that farmers are quite reluctant to give up their traditional and long-lasting expertise, the conservation of which is much more important to them than the potential increase in income from afforestation [82]. Moreover, for afforestation, a distinction should be made between high-rent intensive arable land (ARA) and low-rent mosaic farmland and pastures (MCP) [85]. Transitions from agriculture to forests are not likely to take place in cases of ARA, whereas they are more likely in cases of $\mathrm{MCP}$, since the comparatively high rents of forest farming are a relevant incentive towards land cover change [85]. Moreover, ARA and MCP, with the addition of OPSP, show similar shares of the total regional land cover, that is $27 \%$ and $25 \%$, respectively, as reported in the last column of Table 3, and their spatial layout is characterized by a nearly homogeneous distribution across the regional territory. Policy measures aiming at implementing a decrease in LST should be based on targeting both ARA and MCP, as follows. A system of afforestation incentives should be implemented, targeting rural areas on the basis of agricultural rent, with the aim of encouraging low-rent farmers to turn into forest farmers. It is highly likely that these incentives are effective in cases of rural areas classified as either MCP or OPSP, whereas high-rent farming, which mainly takes place in ARA, should be less interested in implementing land cover changes [86]. From this perspective, regional and local planning authorities should carefully assess whether, and to what extent, it is worth extending afforestation across high-rent agricultural land, since, on the one hand, the public financial effort may be overwhelming, and, on the other hand, a weakened agriculture may cause a dramatic decline in the environmental and socio-economic conditions of rural societies [87]. A fundamental role has to be played by national, regional, and local administrations in order to identify the optimal size of afforestation-related land cover transitions and of public investment in terms of financial feasibility [88]. Public commitment to decrease LST in rural areas is very important as regards the effectiveness of planning policies, and it should be visible to the local communities through, for instance, the direct purchase of private rural land, such as low-rent croplands or abandoned, poorly vegetated open spaces, in order to develop afforestation processes [89].

\section{Conclusions}

The methodological approach defined and implemented in this study as regards the Sardinian region provides estimates of the quantitative size of the impact of public policies concerning urban and rural contexts. The outcomes of the regression model not only entail that public planning policies aimed at decreasing LST and mitigating its negative effects on quality of life should build on the implementation of green facades and roofs and blue and green urban grids and infrastructure in urbanized areas, and on afforestation processes in rural zones, but also give quantitative estimates related to the size of the impact on LST generated by the implementation of such policies. This information is very important in order to motivate public financial efforts towards the LST issue in budgetary terms. Moreover, the methodology defined and implemented in this study can be easily exported to other national and European regional contexts, since worldwide and free satellite images the enable the identification of the spatial distribution of LST are available, and the CORINE land-cover-based LEAC taxonomy is available for all European countries.

As regards the outcomes of this study, there are two main directions for future research in the field of spatial planning policies to decrease LST and mitigate the connected problems, which consist of heat waves and heat islands, and quality of life in rural and urban areas. On the one hand, a network of direct, on-site observations would be of fundamental importance as regards the validation of the spatial layout of LST, which would make feasible the experimental implementation of planning 
policies aimed at generating impacts on LST. No planning experiment could be developed in the absence of a validated baseline dataset related to LST. On the other hand, tests and pilot projects involving municipal administrations would be very useful to test the effectiveness of policies such as the afforestation or urban blue and green grids. Researchers in the field of sustainability-oriented planning and local public administrations should therefore lobby local, national, and international funding agencies so as to secure enough funds to implement experimental programs concerning decreasing LST, including pilot actions and local tests.

Author Contributions: S.L., F.L., and C.Z. collaboratively designed this study. Individual contributions are as follows: F.L. wrote Section 1; S.L. wrote Sections 2.1, 2.2, 2.3.1, 2.3.2, and 2.3.3; C.Z. wrote Section 2.3.4; S.L. wrote Section 3.1; C.Z. wrote Section 3.2; F.L. wrote Section 4; C.Z. wrote Section 5. Appendix A was written by S.L. All authors have read and agreed to the published version of the manuscript.

Funding: This research received no external funding.

Acknowledgments: The study was implemented within the Research Program "Paesaggi rurali della Sardegna: pianificazione di infrastrutture verdi e blu e di reti territoriali complesse" [Rural landscapes of Sardinia: Planning policies for green and blue infrastructure and spatial complex networks], funded by the Autonomous Region of Sardinia for the period 2019-2021, under the provisions of the call for the presentation of "Projects related to fundamental or basic research" of the year 2017, implemented at the Department of Civil and Environmental Engineering and Architecture (DICAAR) of the University of Cagliari, Italy.

Conflicts of Interest: The authors declare no conflict of interest.

\section{Appendix A}

In this appendix, the process whereby the five LST maps were retrieved from the five selected Landsat images, summarized in Section 2.3.1, is presented in full. The process comprised five steps as follows.

In the first step, the top-of-atmosphere spectral radiance was calculated for each pixel using thermal Landsat 8's band 10 pixel values as input, using equation (A1) [39]:

$$
\mathrm{TOA}=\left(\mathrm{M}_{\mathrm{L}} \cdot \mathrm{Q}_{\mathrm{cal}}\right)+\mathrm{A}_{\mathrm{L}}
$$

where:

- TOA is the top-of-atmosphere spectral radiance $\left(\mathrm{W} /\left(\mathrm{m}^{2} \cdot \mathrm{sr} \cdot \mu \mathrm{m}\right)\right)$;

- $\mathrm{M}_{\mathrm{L}}$ is the band-specific multiplicative rescaling factor (retrievable from the image's metadata, provided by USGS as a plain text file together with the image, as "RADIANCE_MULT_BAND_10");

- $\mathrm{Q}_{\text {cal }}$ is the band 10 image pixel values (i.e., digital numbers), quantized and calibrated;

- $\mathrm{A}_{\mathrm{L}}$ is the band-specific additive rescaling factor (retrievable from the image's metadata, provided by USGS as plain text file together with the image, as "RADIANCE_ADD_BAND_10").

In the second step, the top-of-atmosphere spectral radiance was converted into the top-of-atmosphere brightness temperature as per equation (A2) [39]:

$$
B T=\frac{K_{2}}{\ln \left(\frac{K_{1}}{T O A}+1\right)}
$$

where:

- $\quad \mathrm{BT}$ is the top-of-atmosphere brightness temperature (K);

- TOA is the top-of-atmosphere spectral radiance;

- $\mathrm{K}_{1}$ and $\mathrm{K}_{2}$ are two specific thermal conversion constants (retrievable from the image's metadata, provided by USGS as a plain text file together with the image, as “K1_CONSTANT_BAND_10" and “K2_CONSTANT_BAND_10", respectively). 
In the third step, the normalized difference vegetation index was calculated using Landsat 8's bands 4 and 5 images as inputs, through equation (A3) [40]:

$$
N D V I=\frac{N I R-R e d}{N I R+R e d}
$$

where:

- $\quad$ NDVI is the normalized difference vegetation index;

- $\quad$ NIR is the near-infrared band. For Landsat 8 images, this is band 5;

- $\quad$ Red is the visible red band. For Landsat 8 images, this is band 4 .

Once the NDVI was known, in the fourth step, Land Surface Emissivity (LSE) was calculated using various algorithms. Among those implemented in the plugin, Zhang, Wang, and Li's algorithm [41] was chosen here because it was reported to yield the best results [35] as per LST retrieval. This algorithm, which builds upon van de Griend and Owe's findings concerning the correlation between LSE and NDVI [42], can be summarized in Table A1.

Table A1. Relation between Land Surface Emissivity (LSE) and the normalized difference vegetation index (NDVI). Source: [35].

\begin{tabular}{cc}
\hline NDVI & LSE \\
\hline NDVI $<-0.185$ & 0.995 \\
$-0.185 \leq \mathrm{NDVI}<0.157$ & 0.985 \\
$0.157 \leq \mathrm{NDVI} \leq 0.727$ & $1.009+0.047 \cdot \ln (\mathrm{NDVI})$ \\
$\mathrm{NDVI}>0.727$ & 0.990 \\
\hline
\end{tabular}

Finally, in the fifth step, LST was calculated using the so-called "Planck function", which is reported to be "easier to use in comparison to the other algorithms as it does not require atmospheric variables" [35] (p. 28). Among the algorithms implemented in the plugin, equation (A4) [43] was therefore chosen:

$$
L S T=\frac{B T}{1+\left(\lambda \cdot \frac{B T}{\alpha}\right) \cdot \ln (\mathrm{LSE})}
$$

where:

- $\quad$ LST is land surface temperature $(\mathrm{K})$;

- $\quad \mathrm{BT}$ is top-of-atmosphere brightness temperature (K);

- LSE is land surface emissivity;

- $\lambda$ is wavelength of the emitted radiance $(\mathrm{m})=1.0895 \cdot 10^{-5} \mathrm{~m}$ for Landsat 8 TIRS [90];

- $\alpha=h \cdot c / \sigma$ (where $h$ is Planck's constant, $\mathrm{c}$ is the velocity of light, and $\sigma$ is Boltzmann's constant $)=$ $1.438 \cdot 10^{-2} \mathrm{mK}[91]$.

\section{References}

1. Nguyen, T.M.; Lin, T.-H.; Chan, H.-P. The environmental effects of urban development in Hanoi, Vietnam from satellite and meteorological observations from 1999-2016. Sustainability 2019, 11, 1768. [CrossRef]

2. Chadchan, J.; Shankar, R. Emerging urban development issues in the context of globalisation. J. ITPI 2009, 6, 78-85.

3. Cui, L.; Shi, J. Urbanization and its environmental effects in Shanghai, China. Urban Clim. 2012, 2, 1-15. [CrossRef]

4. Kim, Y.-H.; Baik, J.-J. Spatial and temporal structure of the urban heat island in Seoul. J. Appl. Meteorol. 2005, 44, 591-605. [CrossRef]

5. Munafò, M. (Ed.) Consumo di Suolo, Dinamiche Territoriali e Servizi Ecosistemici. Edizione 2019; Report SNPA 08/19 [Land Take, Territorial Dynamics and Ecosystem Services. 2019 Edition. SNPA Report SNPA 08/19, 2019]; SNPA: Atlanta, GA, USA, 2019; ISBN 978-88-448-0964-5. 
6. Feizizadeh, B.; Blaschke, T.; Nazmfar, H.; Akbari, E.; Kohbanani, H.R. Monitoring land surface temperature relationship to land use/land cover from satellite imagery in Maraqeh County, Iran. J. Environ. Plann. Manag. 2013, 56, 1290-1315. [CrossRef]

7. Fonseka, H.P.U.; Zhang, H.; Sun, Y.; Su, H.; Lin, H.; Lin, Y. Urbanization and its impacts on land surface temperature in Colombo metropolitan area, Sri Lanka, from 1988 to 2016. Remote Sens. 2019, 11, 957. [CrossRef]

8. Hofierka, J.; Gallay, M.; Onačillová, K.; Hofierka, J., Jr. Physically-based land surface temperature modeling in urban areas using a 3-D city model and multispectral satellite data. Urban Clim. 2020, 31, 100566. [CrossRef]

9. Lv, Z.; Zhou, Q. Utility of Landsat image in the study of land cover and land surface temperature change. Procedia Environ. Sci. 2011, 10, 1287-1292. [CrossRef]

10. Neinavaz, E.; Skidmore, A.K.; Darvishzadeh, R. Effects of prediction accuracy of the proportion of vegetation cover on land surface emissivity and temperature using the NDVI threshold method. Int. J. Appl. Earth Obs. Geoinf. 2020, 85, 101984. [CrossRef]

11. Wang, C.; Li, Y.; Myint, S.W.; Zhao, Q.; Wentz, E.A. Impacts of spatial clustering of urban land cover on land surface temperature across Köppen climate zones in the contiguous United States. Landsc. Urban Plan. 2019, 92, 103668. [CrossRef]

12. Li, X.X.; Koh, T.Y.; Panda, J.; Norford, L.K. Impact of urbanization patterns on the local climate of a tropical city, Singapore: An ensemble study. J. Geophys. Res. Atmos. 2016, 121, 4386-4440. [CrossRef]

13. Alfraihat, R.; Mulugeta, G.; Gala, T. Ecological evaluation of urban heat island in Chicago City, USA. J. Atmos. Pollut. 2016, 4, 23-29. [CrossRef]

14. Chaudhuri, G.; Mishra, N.B. Spatio-temporal dynamics of land cover and land surface temperature in Ganges-Brahmaputra delta: A comparative analysis between India and Bangladesh. Appl. Geogr. 2016, 68, 68-83. [CrossRef]

15. Tran, D.X.; Pla, F.; Latorre-Carmona, P.; Myint, S.W.; Caetano, M.; Kieu, H.V. Characterizing the relationship between land use land cover change and land surface temperature. ISPRS J. Photogramm. 2017, 124, 119-132. [CrossRef]

16. Jiang, Y.; Fu, P.; Weng, Q. Assessing the impacts of urbanization-associated land use/cover change on land surface temperature and surface moisture: A case study in the Midwestern United States. Remote Sens. 2015, 7, 4880-4898. [CrossRef]

17. Kayet, N.; Pathak, K.; Chakrabarty, A.; Sahoo, S. Spatial impact of land use/land cover change on surface temperature distribution in Saranda Forest, Jharkhand. Model. Earth Syst. Environ. 2016, 2, 127. [CrossRef]

18. Sahana, M.; Ahmed, R.; Sajjad, H. Analyzing land surface temperature distribution in response to land use/land cover change using split window algorithm and spectral radiance model in Sundarban Biosphere Reserve, India. Model. Earth Syst. Environ. 2016, 2, 81. [CrossRef]

19. Zullo, F.; Fazio, G.; Romano, B.; Marucci, A.; Fiorini, L. Effects of urban growth spatial pattern (UGSP) on the land surface temperature (LST): A study in the Po Valley (Italy). Sci. Total Environ. 2019, 650, 1740-1751. [CrossRef]

20. Guha, S.; Govil, H.; Dey, A.; Gill, N. Analytical study of land surface temperature with NDVI and NDBI using Landsat 8 OLI and TIRS data in Florence and Naples city, Italy. Eur. J. Remote Sens. 2018, 51, 667-678. [CrossRef]

21. Stroppiana, D.; Antoninetti, M.; Brivio, P.A. Seasonality of MODIS LST over Southern Italy and correlation with land cover, topography and solar radiation. Eur. J. Remote Sens. 2014, 47, 133-152. [CrossRef]

22. Scarano, M.; Sobrino, J.A. On the relationship between the sky view factor and the land surface temperature derived by Landsat-8 images in Bari, Italy. Int. J. Remote Sens. 2015, 36, 4820-4835. [CrossRef]

23. Ding, H.; Shi, W. Land-use/land-cover change and its influence on surface temperature: A case study in Beijing City. Int. J. Remote Sens. 2013, 34, 5503-5517. [CrossRef]

24. Copernicus Project Database-Europe's Eyes on Earth. Available online: https://www.copernicus.eu (accessed on 11 April 2020).

25. EEA. CORINE Land Cover. 1995. Available online: http://www.eea.europa.eu/publications/COR0-landcover (accessed on 11 April 2020).

26. EEA. Land Accounts for Europe 1990-2000: Towards Integrated Land and Ecosystem Accounting; European Environment Agency Report No. 11; Office for Official Publications of the European Communities: Luxembourg, 2006; ISBN 92-9167-888-0. 
27. SardegnaStatistiche-Popolazione e Famiglie-Popolazione (2007-2019). Available online: http://www. sardegnastatistiche.it/documenti/12_103_20191028124604.ods (accessed on 11 April 2020).

28. Canu, S.; Rosati, L.; Fiori, M.; Motroni, A.; Filigheddu, R.; Farris, E. Bioclimate map of Sardinia (Italy). J. Maps 2015, 11, 711-718. [CrossRef]

29. Pungetti, G.; Marini, A.; Vogiatzakis, I. Sardinia. In Mediterranean Island Landscapes; Landscape Series; Vogiatzakis, I., Pungetti, G., Mannion, A.M., Eds.; Springer: Dordrecht, Germany, 2008; Volume 9, pp. 143-169. [CrossRef]

30. Cardil, A.; Salis, M.; Spano, D.; Delogu, G.; MolinaTerrén, D. Large wildland fires and extreme temperatures in Sardinia (Italy). iForest 2014, 7, 162-169. [CrossRef]

31. USGS. Science for a Changing World-EarthExplorer. Available online: https://earthexplorer.usgs.gov/ (accessed on 11 April 2020).

32. Kosztra, B.; Büttner, G.; Hazeu, G.; Arnold, S. Updated CLC Illustrated Nomenclature Guidelines; Environment Agency Austria: Vienna, Austria, 2019.

33. CLC. 2018. Available online: https://land.copernicus.eu/pan-european/corine-land-cover/clc2018 (accessed on 11 April 2020).

34. DTM Passo 10 Metri [DTM Sampling Rate 10]. Available online: http://webgis2.regione.sardegna.it/ catalogodati/card.jsp?uuid=R_SARDEG:JDCBN (accessed on 11 April 2020).

35. Ndossi, M.I.; Avdan, U. Application of open source coding technologies in the production of Land Surface Temperature (LST) maps from Landsat: A PyQGIS Plugin. Remote Sens. 2016, 8, 413. [CrossRef]

36. Barbierato, E.; Bernetti, I.; Capecchi, I.; Saragosa, C. Quantifying the impact of trees on land surface temperature: A downscaling algorithm at city-scale. Eur. J. Remote Sens. 2019, 52, 74-83. [CrossRef]

37. Alves, E.D.L. Seasonal and spatial variation of surface urban heat island intensity in a small urban agglomerate in Brazil. Climate 2016, 4, 61. [CrossRef]

38. Dhar, R.B.; Chakraborty, S.; Chattopadhyay, R.; Sikdar, P.K. Impact of land-use/land-cover change on land surface temperature using satellite data: A case study of Rajarhat Block, North 24-Parganas District, West Bengal. J. Indian Soc. Remot. 2019, 47, 331-348. [CrossRef]

39. USGS. Using the USGS Landsat Level-1 Data Product. Available online: https://www.usgs.gov/landresources/nli/landsat/using-usgs-landsat-level-1-data-product (accessed on 11 April 2020).

40. Townshend, J.R.G.; Goff, T.E.; Tucker, C.J. Multitemporal dimensionality of images of normalized difference vegetation index at continental scales. IEEE Trans. Geosci. Remote 1985, GE-23, 888-895. [CrossRef]

41. Zhang, J.; Wang, Y.; Li, Y. A C++ Program for retrieving land surface temperature from the data of Landsat TM/ETM+ band6. Comput. Geosci. 2006, 32, 1796-1805. [CrossRef]

42. van de Griend, A.A.; Owe, M. On the relationship between thermal emissivity and the normalized different vegetation index for natural surfaces. Int. J. Remote Sens. 1993, 14, 1119-1131. [CrossRef]

43. Artis, D.A.; Carnahan, W.H. Survey of emissivity variability in thermography of urban areas. Remote Sens. Environ. 1982, 12, 313-329. [CrossRef]

44. ArcGis Help. Resample. Available online: https://pro.arcgis.com/en/pro-app/tool-reference/datamanagement/resample.htm (accessed on 11 April 2020).

45. EPSG 32632. Available online: https://epsg.io/32632 (accessed on 11 April 2020).

46. Cheshire, P.; Sheppard, S. On the price of land and the value of amenities. Econ. New Ser. 1995, 62, $247-267$. [CrossRef]

47. Stewart, P.A.; Libby, L.W. Determinants of farmland value: The case of DeKalb County, Illinois. Rev. Agric. Econ. 1998, 80-95. [CrossRef]

48. Sklenicka, P.; Molnarova, K.; Pixova, K.C.; Salek, M.E. Factors affecting farmlands in the Czech Republic. Land Use Policy 2013, 30, 130-136. [CrossRef]

49. Zoppi, C.; Argiolas, M.; Lai, S. Factors influencing the value of houses: Estimates for the city of Cagliari, Italy. Land Use Policy 2015, 42, 367-380. [CrossRef]

50. Bera, A.K.; Byron, R.P. Linearised estimation of nonlinear single equation functions. Int. Econ. Rev. 1983, 24, 237-248. [CrossRef]

51. Wolman, A.L.; Couper, E. Potential consequences of linear approximation in economics. Fed. Reserve Bank Richmond Econ. Q. 2003, 89, 51-68.

52. Oke, T.R. The urban energy balance. Prog. Phys. Geogr. Earth Environ. 1988, 12, 471-508. [CrossRef] 
53. Geneletti, D.; Cortinovis, C.; Zardo, L.; Blam Adel, E. Planning for Ecosystem Services in Cities; Springer: Dordrecht, Germany, 2019. [CrossRef]

54. Skelhorn, C.; Lindley, S.; Levermore, G. The impact of vegetation types on air and surface temperatures in a temperate city: A fine scale assessment in Manchester, UK. Landsc. Urban Plan. 2014, 121, 129-140. [CrossRef]

55. Demuzere, M.; Orru, K.; Heidrich, O.; Olazabal, E.; Geneletti, D.; Orru, H.; Bhave, A.G.; Mittal, N.; Feliu, E.; Faehnle, M. Mitigating and adapting to climate change: Multi-functional and multi-scale assessment of green urban infrastructure. J. Environ. Manag. 2014, 146, 107-115. [CrossRef] [PubMed]

56. Fischer, E.M.; Schär, C. Consistent geographical patterns of changes in high-impact European heatwaves. Nat. Geosci. 2010, 3, 398-403. [CrossRef]

57. Irmak, A. (Ed.) Remote Sensing and Modeling; IntechOpen: London, UK, 2012. [CrossRef]

58. Launeau, P.; Giraud, M.; Ba, A.; Moussaoui, S.; Robin, M.; Debaine, F.; Lague, D.; Le Menn, E. Full-waveform LiDAR pixel analysis for low-growing vegetation mapping of coastal foredunes in Western France. Remote Sens. 2018, 10, 669. [CrossRef]

59. Ge, J. MODIS observed impacts of intensive agriculture on surface temperature in the southern Great Plains. Int. J. Climatol. 2010, 30, 1994-2003. [CrossRef]

60. Youneszadeh, S.; Amiri, N.; Pilesjo, P. The effect of land use change on land surface temperature in the Netherlands. In Proceedings of the International Conference on Sensors \& Models in Remote Sensing \& Photogrammetry, Kish Island, Iran, 23-25 November 2015; Volume 41, pp. 745-748.

61. Zhou, W.; Qian, Y.; Li, X.; Li, W.; Han, L. Relationships between land cover and the surface urban heat island: Seasonal variability and effects of spatial and thematic resolution of land cover data on predicting land. Landsc. Ecol. 2014, 29, 153-167. [CrossRef]

62. Walawender, J.P.; Szymanowski, M.; Hajto, M.J.; Bokwa, A. Land surface temperature patterns in the urban agglomeration of Krakow (Poland) derived from Landsat-7/ETM+ Data. Pure Appl. Geophys. 2014, 171, 913-940. [CrossRef]

63. Feldhake, C.M.; Glenn, D.M.; Peterson, D.L. Pasture soil surface temperature response to drought. Agron. J. 1996, 88, 652-656. [CrossRef]

64. Mokhtari, A.; Mansor, S.B.; Mahmud, A.R.; Helmi, Z.M. Monitoring the impacts of drought on land use/cover: A developed object-based algorithm for NOAA AVHRR time series data. J. Appl. Sci. 2011, 11, 3089-3103. [CrossRef]

65. Sruthi, S.; Aslam, M.A.M. Agricultural drought analysis using the NDVI and land surface temperature data: A case study of Raichur District. Aquat. Proc. 2015, 4, 1258-1264. [CrossRef]

66. Dodo, M.K. Examining the potential impacts of climate change on international security: EU-Africa partnership on climate change. SpringerPlus 2014, 3, 194. [CrossRef]

67. Kaniewski, D.; Marriner, N.; Cheddadi, R.; Fischer, P.M.; Otto, T.; Luce, F.; Van Campo, E. Climate change and social unrest: A 6000-year chronicle from the eastern Mediterranean. Geophys. Res. Lett. 2020, $47,7$. [CrossRef]

68. Centro Studi di Confagricoltura [Study Center of the Italian Confederation of Agriculture]. L'agricoltura Nelle Regioni d'Italia-2015—Sardegna [The Agriculture in the Italian Regions—2015—Sardinia]. Available online: http://www.confagricoltura.it/DownLoadFileUrl.php/url=backend@@comunicazioni@ @file_upload@@allegato@@1701171100150_20_sardegna.pdf/nomefile=20_sardegna.pdf (accessed on 11 April 2020).

69. Mayor of London. London's Urban Heat Island: A Summary for Decision Makers; Greater London Authority, City Hall: London, UK, 2006.

70. Nguyen, T.T.; Bauer, S.; Uibrig, H. Land privatization and afforestation incentive of rural farms in the Northern Uplands of Vietnam. For. Policy Econ. 2010, 12, 518-526. [CrossRef]

71. Pötz, H.; Sjauw En Wa-Windhorst, A.; van Someren, H. Urban Green-Blue Grids Manual for Resilient Cities; Atelier Groenblauw: Delft, The Netherlands, 2016.

72. Gómez-Baggethun, E.; Barton, D.N. Classifying and valuing ecosystem services for urban planning. Ecol. Econ. 2013, 86, 235-245. [CrossRef] 
73. Mathey, J.; Rößler, S.; Lehmann, I.; Bräuer, A. Urban green spaces: Potentials and constraints for urban adaptation to climate change. In Resilient Cities. Cities and Adaptation to Climate Change. Proceedings of the Global Forum 2010, Munich, Germany, 19-20 May 2010; Otto-Zimmermann, K., Ed.; Springer: Dordrecht, Germany, 2011; Volume 1, pp. 479-485. [CrossRef]

74. Jenning, V.; Larson, L.; Yun, J. Advancing sustainability through urban green space: Cultural ecosystem services, equity, and social determinants of health. Int. J. Environ. Res. Public Health 2016, 13, 196. [CrossRef] [PubMed]

75. Webster, C. The new institutional economics and the evolution of modern urban planning: Insights, issues and lessons. Town Plan. Rev. 2005, 76, 455-502. [CrossRef]

76. Bramley, G.; Watkins, D.G. 'Measure twice, cut once'-Revisiting the strength and impact of local planning regulation of housing development in England. Environ. Plan. B 2014, 41, 863-884. [CrossRef]

77. Buijs, A.; Hansen, R.; Van der Jagt, S.; Ambrose-Oji, B.; Elands, B.; Lorance Rall, E.; Mattijssen, T.; Pauleit, S.; Runhaar, H.; Stahl Olafsson, A.; et al. Mosaic governance for urban green infrastructure: Upscaling active citizenship from a local government perspective. Urban For. Urban Green. 2019, 40, 53-62. [CrossRef]

78. Slätmo, E.; Nilsson, K.; Turunen, E. Implementing green infrastructure in spatial planning in Europe. Land 2019, 8, 62. [CrossRef]

79. Fors, H.; Frøik Molin, J.; Murphy, M.A.; Konijnendijk van den Boschab, C. User participation in urban green spaces-For the people or the parks? Urban For. Urban Green. 2015, 14, 722-734. [CrossRef]

80. Pérez-Urrestarazu, L.; Fernández-Cañero, R.; Franco-Salas, A.; Egea, G. Vertical greening systems and sustainable cities. J. Urban Technol. 2015, 22, 65-85. [CrossRef]

81. Wall, S. Small-scale Forestry and Rural Development: The Intersection of Ecosystems, Economics and Society. Proceedings of IUFRO 3.08 Conference Hosted by Galway-Mayo Institute of Technology, Galway, Ireland, 3-6 July 2006; COFORD: Dublin, Irish, 2006.

82. Ryan, M.; O’Donoghue, C. Socio-economic drivers of farm afforestation decision-making. Ir. For. J. 2016, 73, 96-121.

83. Howley, P.; Buckley, C.; O'Donoghue, C.; Ryan, M. Explaining the economic "irrationality" of farmers' land use behaviour: The role of productivist attitudes and non-pecuniary benefits. Ecol. Econ. 2015, 109, 186-193. [CrossRef]

84. Duesberg, S.; Ní Dhubháin, A.; O'Connor, D. Assessing policy tools for encouraging farm afforestation in Ireland. Land Use Policy 2014, 38, 194-203. [CrossRef]

85. Kumm, K.I.; Hessle, A. Economic comparison between pasture-based beef production and afforestation of abandoned land in Swedish forest districts. Land 2020, 9, 42. [CrossRef]

86. Hyytiainen, K.; Leppanen, J.; Pahkasalo, T. Economic analysis of field afforestation and forest clearance for cultivation in Finland. In Proceedings of the International Congress of European Association of Agricultural Economists, Ghent, Belgium, 26-29 August 2008.

87. Behan, J.; McQuinn, K.; Roche, M.J. Rural land use: Traditional agriculture or forestry? Land Econ. 2006, 82, 112-123. [CrossRef]

88. Zavalloni, M.; D'Alberto, R.; Raggi, M.; Viaggi, D. Farmland abandonment, public goods and the CAP in a marginal area of Italy. Land Use Policy 2019, in press. [CrossRef]

89. Brouwer, R.; Lienhoop, N.; Oosterhuis, F. Incentivizing afforestation agreements: Institutional-economic conditions and motivational drivers. J. For. Econ. 2015, 21, 205-222. [CrossRef]

90. Zhao, C.; Jensen, J.; Weng, Q.; Weaver, R. A geographically weighted regression analysis of the underlying factors related to the surface urban heat island phenomenon. Remote Sens. 2018, 10, 1428. [CrossRef]

91. Avdan, U.; Jovanovska, G. Algorithm for automated mapping of land surface temperature using LANDSAT 8 satellite data. J. Sens. 2016. [CrossRef]

(C) 2020 by the authors. Licensee MDPI, Basel, Switzerland. This article is an open access article distributed under the terms and conditions of the Creative Commons Attribution (CC BY) license (http://creativecommons.org/licenses/by/4.0/). 